\title{
Manfaat pemberian tepung daun kelor (Moringa oleifera) terhadap kadar IL-6 dan kolesterol LDL tikus Sprague Dawley dislipidemia Benefits of supplementation moringa leafflour (Moringa oleifera) on IL-6 and LDL levels of Sprague Dawley dyslipidemia rats
}

\author{
Welresna J.P Rupiasa1, Siti Fatimah-Muis ${ }^{2 *}$, Ahmad Syauqy3 ${ }^{3}$ Kusmiyati Tjahjono4, \\ Gemala Anjani 5
}

\author{
1 Pascasarjana Program Studi Magister \\ Ilmu Gizi, Fakultas Kedokteran, \\ Universitas Diponegoro, Semarang, \\ Jawa Tengah, Indonesia. \\ Email: welresnarupiasa07@gmail.com \\ 2 Departemen Ilmu Gizi, Fakultas \\ Kedokteran, Universitas Diponegoro, \\ Semarang, Jawa Tengah, Indonesia. \\ Email: sitifatimahmuis@gmail.com \\ 3 Departemen Ilmu Gizi, Fakultas \\ Kedokteran, Universitas Diponegoro, \\ Semarang, Jawa Tengah, Indonesia. \\ Email: bangyoki@yahoo.com \\ 4 Fakultas Kedokteran, Universitas \\ Diponegoro, Semarang, Jawa Tengah, \\ Indonesia. Email: kusmiceria@gmail.com \\ 5 Departemen Ilmu Gizi, Fakultas \\ Kedokteran, Universitas Diponegoro, \\ Semarang, Jawa Tengah, Indonesia. \\ Email: gemaanjani@gmail.com
}

\section{*Korespondensi:}

Departemen Ilmu Gizi, Fakultas Kedokteran, Universitas Diponegoro. Jln. Prof. Sudarto SH, Tembalang, Semarang, Jawa Tengah, Indonesia.Email: sitifatimahmuis@gmail.com

\section{Riwayat Artikel:}

Diterima tanggal 15 Juni 2021; Direvisi tanggal 24 Juli 2021; Disetujui tanggal 04 Agustus 2021; Dipublikasi tanggal 30 Nopember 2021.

Penerbit:

Politeknik Kesehatan Aceh Kementerian Kesehatan R

(C) The Author(s). 2021 Open Access

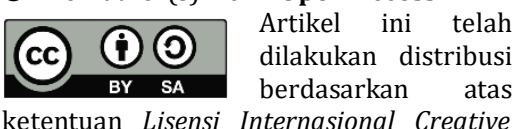
Commons Attribution 4.0

\begin{abstract}
Dyslipidemia condition causes oxidative stress that triggers inflammation. Moringa leaves are rich in fiber and antioxidants that can prevent oxidative stress and reduce inflammation. This study aimed to see, measure, and analyze the effect of Moringa flour supplementation on IL-6 and LDL levels of dyslipidemic Sprague Dawley (SD) rats. The type of study was true-experiment with randomized pre-post. Test with control. Group design. Intervention for 28 days in 4 groups of SD rats $(n=24)$; a consisting group of healthy rats $(K-)$, dyslipidemic rats $(\mathrm{K}+)$, dyslipidemic rats respectively given $0.1 \mathrm{~g} / 100 \mathrm{~g} B W$ moringa flour (P1), and $0.2 \mathrm{~g} / 100 \mathrm{~g}$ BW moringa flour (P2). ELISA and CHODPAP methods measured IL- 6 and LDL levels. Statistical analysis used Paired ttest, One-way Anova, and Post Hoc Bonferroni. The results showed a significant decrease in IL- 6 and LDL levels in the intervention group compared to the non-intervention group ( $p=0,000)$. The reduction of IL- 6 levels in the P2 group was greater than that in the P1 group but not significant. The decrease. in LDL levels in the P2 group was significantly higher than in the P1 group. It is attributed to the fiber and antioxidant content in Moringa. Fiber that can bind cholesterol and bile acids, antioxidants can regulate fat metabolism, capture free radicals and prevent oxidative stress. In conclusion, Moringa flour supplementation improved lipid profiles and inflammation compared to rats with only standard and high-fat diets.
\end{abstract}

Keywords: Dyslipidemia, IL-6, LDL, moringa flour

\section{Abstrak}

Kondisi dislipisemia menyebabkan stres oksidatif yang memicu inflamasi. Daun kelor kaya akan serat dan antioksidan yang dapat mencegah stres oksidatif serta inflamasi. Penelitian ini bertujuan melihat, mengukur serta menganalisis pengaruh sumplementasi tepung kelor terhadap kadar IL-6 dan LDL tikus Sprague Dawley (SD) dislipidemia. Jenis penelitian true eksperimental dengan randomized prepost test with control group design. Sampel yang digunakan adalah tikus putih Sprague Dawley, usia 8-12 minggu, dengan berat badan 150-200 gram, kondisi tikus tanpa cacat fisik. Intervensi selama 28 hari pada 4 kelompok tikus SD $(\mathrm{n}=24)$; kelompok tikus sehat $(\mathrm{K}-)$, tikus dislipidemia $(\mathrm{K}+)$, tikus dislipidemia dengan intervensi tepung kelor 0,1g/100g BB (P1), tikus dislipidemia dengan intervensi tepung kelor 0,2 g/100g BB (P2). Kadar IL-6 dan LDL diukur dengan metode ELISA dan CHODPAP. Analisis statistik menggunakan Paired t-test, One way Anova dan Post Hoc Bonferroni. Hasil penelitian menunjukkan terjadi penurunan bermakna kadar IL-6 dan LDL setelah intervensi tepung daun kelor $(p=0,000)$. Penurunan kadar IL-6 kelompok P2 lebih besar dari P1 namun tidak bermakna. Penurunan kadar LDL kelompok P2 secara bermakna lebih tinggi dari P1. Ini dikaitkan dengan kandungan serat dan antioksidan dalam kelor. Serat dapat mengikat kolesterol dan asam empedu, antioksidan dapat meregulasi 
metabolisme lemak, menangkap radikal bebas sehingga mencegah stres oksidatif. Disimpulkan bahwa, suplementasi tepung kelor memperbaiki profil lipid serta inflamasi dibandingkan kelompok hewan coba yang hanya menerima pakan standar dan pakan tinggi lemak.

Kata Kunci: Dislipidemia, IL-6, LDL, tepung kelor

\section{Pendahuluan}

Dislipidemia adalah sebuah kondisi abnormalitas pada profil lipid dalam darah yang ditandai tingginya kadar LDL dan rendahnya HDL (Linton et al., 2019). Dislipidemia merupakan salah satu faktor risiko utama untuk pengembangan dan perkembangan penyakit kardiovaskular (PKV) (Stein et al., 2019). Data World Health Organization (WHO) tahun 2017 menunjukkan PKV adalah penyebab utama kematian secara global. Data Riskesdas tahun 2018 menunjukkan prevalensi PKV di Indonesia juga mengalami peningkatan. Prevalensi stroke mengalami peningkatan yaitu 7\% (2013) hingga 10,9\% (2018), sedangkan prevalensi Penyakit Jantung Koroner (PJK) tidak mengalami penurunan sejak 2013 yaitu sebesar 1,5\%. Prevalensi penyakit hipertensi menurut diagnosis juga meningkat dari tahun $2013(25,8 \%)$ menjadi 34,1\% pada tahun 2018 (Riskesdas, 2018).

Studi prospektif yang dilakukan oleh Brown (2020) menunjukkan bahwa tingginya kadar LDL dan rendahnya HDL mengakibatkan endapan kolesterol pada dinding pembuluh darah. Kondisi ini menyebabkan LDL teroksidasi sehingga meningkatkan produksi radikal bebas. Keadaan tersebut mengakibatkan ketidakseimbangan antara radikal bebas dengan antioksidan endogen yang dikenal dengan stres oksidatif yang memicu terjadinya kerusakan jaringan dan menyebabkan inflamasi. Ketika terjadi inflamasi, IL-6 yang dilepaskan kedalam sirkulasi menginduksi perubahan suhu tubuh dan menyebabkan demam. Hal ini membuat IL-6 dianggap sebagai biomarker peradangan yang andal (Brown, 2020). Inflamasi yang berkepanjangan akan memicu penyakit kardiovaskular (Ariyanti \& Besral, 2019).

Kandungan antioksidan yang kuat dalam kelor tidak hanya mampu meregulasi metabolisme lemak tetapi juga mampu menangkap radikal bebas (Nile et al., 2018) sehingga dapat melindungi jaringan dari inflamasi dan kerusakan. Dengan demikian, tubuh memerlukan asupan yang mengandung antioksidan untuk melindungi jaringan dari kerusakan akibat peroksidasi lipid.

Pengobatan dislipidemia dapat dilakukan melalui pengelolaan farmakologi maupun nonfarmakologi berupa perubahan pola diet serta penurunan berat badan (Erwinanto et al., 2017). Akan tetapi, obat-obatan farmakologis yang biasanya digunakan ternyata memiliki beberapa efek samping terhadap penggunanya seperti keluhan gastrointestinal, miopati hingga keluhan pada kulit. Hal ini mendorong berbagai pihak untuk mengembangkan bahan alami sebagai alternatif pengobatan. Hal ini didukung dengan sifat tanaman kelor yang dapat tumbuh dimana saja sehingga mudah untuk dikembangkan. Daun kelor kaya akan serat dan berbagai jenis antioksidan seperti tanin, saponin, flavonoid (kuersetin dan kaemferol), asam fenol, alkaloid, $\beta$ - sitosterol, karotenoid, terpenoid, dan isotiosianat dan vitamin C (Aborhyem et al., 2016). Serat larut dalam usus halus mampu mengikat kolesterol, lemak dan asam empedu. Kandungan antioksidan yang kuat dalam kelor tidak hanya mampu meregulasi metabolisme lemak tetapi juga mampu menangkap radikal bebas (Nile et al., 2018). Dengan demikian dapat melindungi jaringan dari kerusakan. Daun Moringa oleifera memiliki efek anti inflamasi secara in vitro menghambat produksi berbagai mediator dan sitokin inflamasi (Ngurah et al., 2021; Syahrial \& Handayani, 2020) dan menurunkan risiko berbagai penyakit kronis yang disebabkan oleh stres oksidatif termasuk penyakit kardiovaskular (Zheng et al., 2017; Chhikara et al., 2020).

Daun kelor dapat disimpan dalam bentuk tepung kering selama berbulan-bulan tanpa kehilangan nilai gizi yang banyak (Isnan, 2017). Selain itu, aktifitas antioksidan dalam daun kelor kering diketahui masih cukup unggul jika dibandingkan dengan beberapa sayuran lain (Rani et al., 2019), serta sangat signifikan dalam meningkatkan pertumbuhan dan perkembangan berat badan (Irwan et al., 2020). Pembuatan daun kelor dalam bentuk tepung dimaksudkan untuk mempermudah pemanfaatan daun kelor kering 
(Isnan \& Muin, 2017). Karena itu, diperlukan penentuan dosis-respons yang tepat dari tepung daun kelor sebagai bahan pangan fungsional. Penelitian tentang pengaruh dosis suplementasi tepung daun kelor terhadap kadar IL-6 dan kadar kolesterol LDL masih sangat jarang dilakukan baik pada hewan coba maupun pada manusia, sehingga peneliti merasa perlu untuk meneliti terkait pengaruh intervensi tepung daun kelor dalam beberapa dosis terhadap kadar IL-6 dan kolesterol LDL pada tikus Sprague Dawley dislipidemia.

Penelitian ini bertujuan untuk mengukur pengaruh intervensi tepung daun kelor terhadap kadar IL-6 dan kadar kolesterol LDL pada tikus Sprague Dawley yang dikondisikan dislipidemia.

\section{Metode}

Penelitian true experimental dilakukan melalui Rancangan Acak Lengkap (RAL) pre and post-test control group design. Pembuatan tepung daun kelor, pemeliharaan hewan coba, dan pemeriksaan biokimia sampel berlangsung pada dari bulan Maret sampai April tahun 2021, dengan lokasi adalah di Laboratorium Gizi Pusat Studi Pangan dan Gizi Universitas Hadjah Mada (UGM), Yogyakarta.

Sampel penelitian adalah tikus jantan Sprague Dawley dari laboratorium penelitian dan pengujian terpadu (LPPT) Universitas Gadjah Mada. Sampel dipilih berdasarkan kriteria inklusi dan eksklusi, dimana kriteria inklusi yaitu tikus putih Sprague Dawley jantan, dengan berat badan 150-200 gram. berumur 8-12 minggu, kondisi tikus sehat tanpa cacat fisik. Tikus dieksklusi ketika: Tikus mengalami obesitas (>300 g), BB $<150 \mathrm{~g}$, Tikus tidak sehat pada periode adaptasi sebelum diacak. Penentuan besar sampel didasarkan pada standar dari World Health Organization (WHO) terkait penggunaan sampel hewan coba untuk pemberian herbal medicine, yaitu 5 ekor/kelompok (World Health Organization, 2000).

Bahan penelitian yaitu daun kelor, pakan standar AD2, reagen pemeriksaan IL-6 dan kolesterol LDL serta pakan tinggi lemak dengan komposisi pakan standar AD2 90\%, 10\% lemak babi dan $2 \mathrm{ml}$ kuning telur bebek (Andini, 2016). Alat yang digunakan dalam penelitian ini berupa cabinet dryer, grinder, homogenizer mixer, kandangan hewan, wadah pakan standar dan minum, sonde lambung, timbangan digital, mikropipet eppendorf. Pemilihan penggunaan lemak babi untuk menginduksi tikus dislipidemia karena tingginya kandungan asam lemak dan kolesterol sehingga mempercepat proses pengkondisian dislipidemia.

Periode aklimatisasi selama 7 hari, 24 ekor tikus menggunakan kandang individu diberi pakan standar $10 \mathrm{~g} /$ hari dan air minum secara ad libitum. Setelah selesai masa aklimatisasi, 24 ekor tikus dibagi ke dalam 4 kelompok untuk dikondisikan dislipidemia selama 14 hari. 4 kelompok tersebut terdiri atas 3 kelompok tikus $\left(\mathrm{K}+, \mathrm{P}_{1}, \mathrm{P}_{2}\right)$ yang diberi pakan. tinggi lemak dan satu kelompok tikus (K-) yang diberi pakan standar. Pengkondisian dislipidemia dilakukan melalui pemberian pakan tinggi lemak selama 14 hari. Pengambilan darah tikus dilakukan pada hari ke-15 sebanyak $3 \mathrm{ml}$ melalui plexus retroorbitalis untuk dianalisis kadar IL-6 dengan uji ELISA dan kadar kolesterol LDL dengan metode CHOD-PAP.

Setelah 14 hari, maka hewan coba akan memasuki masa intervensi selama 28 hari. Pada periode intervensi, setiap kelompok perlakuan baik itu kelompok $\mathrm{P}_{1}$ maupun $\mathrm{P}_{2}$ diberikan tepung kelor sesuai dosis masing-masing yaitu $0,1 \mathrm{~g} / 100 \mathrm{~g}$ BB untuk kelompok $\mathrm{P}_{1}$ dan dosis $0,2 \mathrm{~g} / 100 \mathrm{~g}$ BB untuk kelompok $\mathrm{P}_{2}$. Selain diberi intervensi tepung kelor, hewan coba juga diberi pakan standar $10 \mathrm{~g}$ secara ad libitum dan air minum melalui sonde. Kelompok $\mathrm{K}$ - dan Kelompok K+ tidak diberi intervensi tepung kelor dan hanya menerima pakan standar dan air minum dalam takaran dan metode yang sama. Setelah selesai masa intervensi, kembali dilakukan pengambilan darah tikus pada hari ke29. Darah diambil untuk dianalisis kadar IL-6 dan kadar kolesterol LDL dalam takaran dan metode yang sama dengan sebelumnya.

Langkah pembuatan tepung kelor dimulai dari pengumpulan daun kelor, dan pemisahan daun kelor dari bagian tanaman lainnya. Daun kelor yang digunakan adalah daun segar dan berwarna hijau tua karena memiliki tekstur yang sesuai untuk pembuatan tepung. Daun kelor yang telah dikumpulkan lalu dicuci dan dikeringkan. Pengeringan menggunakan oven dengan suhu $55^{\circ} \mathrm{C}$ selama 60 menit. Suhu pengeringan $55^{\circ} \mathrm{C}$ adalah suhu yang paling optimal untuk kandungan aktivitas antioksidan tinggi (Wulan, 2017).

Deskripsi data yang berdistribusi normal disajikan dalam nilai rerata dan standar deviasi 
sedangkan data yang tidak berdistribusi normal akan disajikan dalam nilai median dan minimummaximum. Analisis statistik menggunakan Paired ttest untuk melihat perbedaan pada kelompok sebelum dan sesudah serta uji Wilcoxon untuk menguji beda antar kelompok perlakuan. Data IL-6 dan kolesterol LDL diuji normalitas menggunakan uji Saphiro Wilk. Data berdistribusi normal (p > $0,05)$ dianalisis menggunakan uji One Way Anova $(\alpha=0,05)$, jika ada perbedaan bermakna, maka dilanjutkan uji post hoc test $(\alpha=0,05)$. Data yang berdistribusi tidak normal $(\mathrm{p}<0,05)$ menggunakan uji Kruskal Wallis. Jika ada perbedaan bermakna, maka dilanjutkan dengan uji Mann Whitney $(\alpha=0,05)$. Penelitian ini telah mendapat persetujuan dari Komite Etik Penelitian Kesehatan Fakultas Kedokteran Universitas Diponegoro Semarang No.115/EC/H/FKUNDIP/XI/2020, tanggal 16 Nopember 2020.

\section{Hasil dan Pembahasan}

Penggunaan diet tinggi lemak selama 14 hari berhasil membuat kondisi dislipidemia pada hewan coba yang ditandai dengan peningkatan dan penurunan pada profil lipid serta peningkatan kadar IL-6 sebagai penanda inflamasi yang melebihi nilai normal (Arsana et al., 2019). Kadar normal IL-6 pada tikus yaitu $<62,5 \mathrm{pg} / \mathrm{mL}$ (Elisa, 2020), sedangkan kadar normal kolesterol LDL pada tikus adalah 7-27,2 mg/dl (Nurhidajah et al., 2019).

Hasil penelitian (Tabel 1) telah menunjukkan bahwa terdapat perubahan nilai profil lipid pada intervensi. Kondisi dilipidemia dibuktikan dari hasil pemeriksaan profil lipid dan status inflamasi hewan coba yang menunjukkan perubahan pada profil lipid dan status inflamasi melebihi nilai normal.

Tabel 1. Rata-rata profil lipid \& IL-6 setelah pemberian pakan tinggi lemak

\begin{tabular}{lccccc}
\hline $\begin{array}{l}\text { Kelompok } \\
\text { Intervensi }\end{array}$ & $\begin{array}{c}\text { K-Total } \\
(\mathrm{mg} / \mathrm{dL})\end{array}$ & $\begin{array}{c}\text { LDL } \\
(\mathrm{mg} / \mathrm{dL})\end{array}$ & $\begin{array}{c}\text { HDL } \\
(\mathrm{mg} / \mathrm{dL})\end{array}$ & $\begin{array}{c}\text { Trigliserida } \\
(\mathrm{mg} / \mathrm{dL})\end{array}$ & $\begin{array}{c}\text { IL-6 } \\
(\mathrm{pg} / \mathrm{ml})\end{array}$ \\
\hline Nilai K- & $95,54 \pm 2,81$ & $23,18 \pm 2,51$ & $86,78 \pm 2,95$ & $73,04 \pm 3,49$ & $40,21 \pm 2,92$ \\
Nilai K+ & $192,13 \pm 3,84$ & $78,73 \pm 1,23$ & $26,26 \pm 2,23$ & $132,01 \pm 2,72$ & $79,40 \pm 3,95$ \\
Nilai $P_{1}$ & $189,44 \pm 4,73$ & $81,24 \pm 1,17$ & $25,0 \pm 1,85$ & $133,21 \pm 2,73$ & $79,40 \pm 3,78$ \\
Nilai $P_{2}$ & $193,89 \pm 3,20$ & $80,05 \pm 1,54$ & $26,52 \pm 2,19$ & $151,05 \pm 1,87$ & $80,95 \pm 2,68$ \\
\hline
\end{tabular}

Keterangan:

$\mathrm{K}-\quad=$ Kelompok Tikus normal sehat dan diberi pakan biasa tanpa tepung daun kelor

$\mathrm{K}+$ = Tikus kelompok kontrol positif diberi pakan tinggi lemak tanpa tepung daun kelor

$\mathrm{P} 1$ = Tikus kelompok perlakuan 1 (pakan tinggi lemak + tepung daun kelor dosis 1)

$\mathrm{P} 2$ = Tikus kelompok perlakuan 2 (pakan tinggi lemak + tepung daun kelor dosis 2)

Konsumsi makanan yang tinggi kolesterol dan asam lemak jenuh akan menyebabkan peningkatan sintesis kolesterol LDL di hepar (Yoeantafara \& Martini, 2017) menghambat pembentukan reseptor LDL, sehingga jumlah kolesterol di dalam darah akan terus meningkat (Sudargo et al., 2017). Peningkatan kadar kolesterol dalam darah akan membuat kolesterol megendap pada dinding pembuluh darah sehingga menimbulkan gangguan pada fungsi endotel, dengan meningkatkan produksi radikal bebas oksigen. Radikal ini menonaktifkan produksi oksida nitrat, yang memiliki sifat anti-inflamasi (Brown, 2020).

Pemaparan radikal bebas dalam sel endotel dinding arteri akan menyebabkan oksidasi LDL. LDL yang teroksidasi memicu berbagai reaksi inflamasi sehingga akan menarik monosit dan neutrofil ke area lesi dan menyebabkan plak ateromatosa makin membesar (Santosa \& Baharuddin, 2020). Akibatnya terbentuk luka yang menarik leukosit ke sekitar dinding pembuluh darah sehingga terjadi pembentukan sel busa. IL-6 kemudian dilepas ke sirkulasi oleh neutrofil dan makrofag serta sel-sel di lokasi infeksi sebagai respon terhadap inflamasi. IL-6 yang dilepaskan dapat menginduksi perubahan suhu tubuh di hipotalamus yang menyebabkan demam.

Karena itulah IL6 dianggap sebagai biomarker peradangan yang andal (Rejeki et al., 2019). Inflamasi yang berkepanjangan akan menebalkan plak pada pembuluh darah sehingga kondisi ini akan mengganggu suplai darah di dalam tubuh dan memicu penyakit kardiovaskular (Ariyanti \& Besral, 2019). Kadar kolesterol LDL mengalami penurunan setelah intervensi tepung daun kelor (Tabel 2). 
Tabel 2. Rata-rata nilai kadar kolesterol LDL (mg/dL) hewan coba pada intervensi tepung kelor

\begin{tabular}{lcccc}
\hline Kelompok & Sebelum Intervensi & Setelah Intervensi & $\Delta$ rerata \pm deviasi & Nilai $\mathrm{p}$ \\
\hline K- $(\mathrm{mg} / \mathrm{dL})$ & $23,18 \pm 2,51^{\mathrm{a}}$ & $24,83 \pm 2,09^{\mathrm{a}}$ & $1,65 \pm 0,73$ & $0,003^{*}$ \\
$\mathrm{~K}+(\mathrm{mg} / \mathrm{dL})$ & $78,73 \pm 1,23^{\mathrm{b}}$ & $80,97 \pm 2,11^{\mathrm{b}}$ & $2,24 \pm 1,25$ & $0,007^{*}$ \\
$\mathrm{P}_{1}(\mathrm{mg} / \mathrm{dL})$ & $81,24 \pm 1,17^{\mathrm{b}}$ & $40,22 \pm 2,21^{\mathrm{c}}$ & $-41,02 \pm 2,11$ & $0,000^{* *}$ \\
$\mathrm{P}_{2}(\mathrm{mg} / \mathrm{dL})$ & $80,05 \pm 1,54^{\mathrm{b}}$ & $27,39 \pm 1,88^{\mathrm{a}}$ & $-52,65 \pm 2,20$ & $0,000^{* *}$ \\
Nilai $^{1}$ & $0,000^{* *}$ & $0,000^{* *}$ & & \\
\hline
\end{tabular}

$P$-value $=$ Paired $t$-test,$p^{1}=$ One Way Anova *Signifikan $(<0,05),{ }^{* *}$ Sangat Signifikan $(<0,001)$ $a, b, c, d=$ uji Post-Hoc Bonferroni
Terdapat perbedaan bermakna pada kadar LDL sebelum dan sesudah intervensi tepung daun kelor di setiap kelompok (Tabel 2). Peningkatan kadar LDL tertinggi yaitu pada kelompok pada $\mathrm{K}+$ sedangkan yang terendah pada kelompok $\mathrm{P}_{2}$. Uji One Way Anova menunjukkan bahwa ada perbedaan bermakna pada kadar LDL antar kelompok. Uji lanjut PostHoc Bonferroni sebelum intervensi menunjukkan perbedaan bermakna terdapat pada kelompok Kdibanding kelompok K+, P1 dan P2. Setelah intervensi, ada perbedaan bermakna pada tiap kelompok kecuali pada kelompok Kdibandingkan $\mathrm{P}_{2}$ (Tabel 2).

Pengelolaan dislipidemia menempatkan LDL sebagai target utama dari konsumsi obat penurun kolesterol (Erwinanto, 2017). Intervensi tepung daun kelor terhadap kadar kolesterol LDL baik pada dosis 0,1 g/BB/hari maupun dosis 0,2 g/BB/hari mampu menurunkan kadar kolesterol LDL, hingga mencapai nilai normal. Akan tetapi, penurunan lebih besar terjadi pada intervensi tepung kelor dosis 2 yaitu $0,2 \mathrm{~g} / \mathrm{BB} /$ hari. Hasil penelitian ini membuktikan bahwa tepung daun kelor dengan dosis yang lebih tinggi memberikan pengaruh penurunan kadar kolesterol LDL lebih cepat.

Mekanisme penurunan kadar kolesterol LDL oleh suplementasi tepung daun kelor dikaitkan dengan kandungan antioksidan melalui mekanisme penurunan sintesis kolesterol serta penurunan absorbsi kolesterol di saluran pencernaan yang diperantarai enzim lipase (Yunarto et al., 2019). Kandungan flavonoid, tanin, saponin, dan $\beta$-sitosterol berperan mengurangi akumulasi trigliserida berlebih di dalam tubuh melalui mekanisme peningkatan aktivitas lipoprotein lipase sehingga secara signifikan mengurangi peningkatan trigliserida dan kolesterol LDL (Helmy et al., 2017) serta memberikan pengaruh signifikan terhadap peningkatan kadar kolesterol HDL (Darrashcytha et al., 2017).

Selain itu, kandungan serat larut di usus halus juga dapat membentuk gel yang dapat mengikat kolesterol, lemak, serta asam empedu untuk dikeluarkan bersama feses. Akibatnya asam empedu di hati akan berkurang. Jika ekskresi asam empedu mengalami peningkatan, maka penyerapan kolesterol dalam tubuh akan berkurang karena sebagian kolesterol berikatan dengan asam empedu keluar bersama feses. Asam empedu yang hilang akan diproduksi kembali oleh hati dengan mengambil kolesterol dari darah sehingga mengurangi kadar kolesterol dalam darah (Pratiwi, 2016).

Penurunan kadar kolesterol LDL berdampak pada penurunan kadar IL-6. Penurunan kadar IL6 setelah intervensi tepung daun kelor dapat dilihat pada tabel 3 .

Tabel 3. Rata-rata nilai kadar IL-6 (pg/ml) hewan coba pada intervensi tepung kelor

\begin{tabular}{lccll}
\hline Kelompok & Sebelum Intervensi & Setelah Intervensi & $\Delta$ retata \pm deviasi & Nilai p \\
\hline K- $(\mathrm{pg} / \mathrm{ml})$ & $40,21 \pm 2,92^{\mathrm{a}}$ & $42,22 \pm 3,19^{\mathrm{a}}$ & $1,86(1,86-2,79)$ & $0,000^{* *}$ \\
$\mathrm{~K}+(\mathrm{pg} / \mathrm{ml})$ & $79,40 \pm 3,95^{\mathrm{b}}$ & $81,72 \pm 3,61^{\mathrm{b}}$ & $2,32 \pm 0,97$ & $0,002^{*}$ \\
$\mathrm{P}_{1}(\mathrm{pg} / \mathrm{ml})$ & $79,40 \pm 3,78^{\mathrm{b}}$ & $58,49 \pm 3,56^{\mathrm{c}}$ & $-20,91 \pm 3,36$ & $0,000^{* *}$ \\
$\mathrm{P}_{2}(\mathrm{pg} / \mathrm{ml})$ & $80,95 \pm 2,68^{\mathrm{b}}$ & $54,78 \pm 2,01^{\mathrm{c}}$ & $-26,18 \pm 2,31$ & $0,000^{* *}$ \\
Nilai p$^{1}$ & $0,000^{* *}$ & $0,000^{* *}$ & & \\
\hline
\end{tabular}

Keterangan:

$\mathrm{K}-\quad=$ Kelompok Tikus normal sehat dan diberi pakan biasa tanpa tepung daun kelor

$\mathrm{K}+\quad$ = Tikus kelompok kontrol positif diberi pakan tinggi lemak tanpa tepung daun kelor

$\mathrm{P} 1$ = Tikus kelompok perlakuan 1 (pakan tinggi lemak + tepung daun kelor dosis 1 )

P2 = Tikus kelompok perlakuan 2 (pakan tinggi lemak + tepung daun kelor dosis 2)

P-value $=$ Paired $t$-test,$p^{1}=$ One Way Anova *Signifikan $(<0,05), * *$ Sangat Signifikan $(<0,001)$ $a, b, c, d=$ uji Post-Hoc Bonferroni 
Hasil analisis statistik Paired t-test telah menunjukkan perbedaan bermakna pada kadar IL-6 sebelum dan sesudah intervensi tepung daun kelor di setiap kelompok. Peningkatan kadar IL-6 tertinggi yaitu pada kelompok pada $\mathrm{K}+$ sedangkan yang terendah pada kelompok $\mathrm{P}_{2}$. Uji One Way Anova menunjukkan bahwa ada perbedaan bermakna pada kadar LDL antar kelompok. Uji lanjut Post-Hoc Bonferroni sebelum intervensi menunjukkan perbedaan bermakna terdapat pada kelompok K- dibanding kelompok $\mathrm{K}+$, P1 dan P2. Setelah intervensi, ada perbedaan bermakna pada tiap kelompok kecuali pada kelompok $\mathrm{P}_{1}$ dibandingkan $\mathrm{P}_{2}$ (Tabel 3).

Intervensi tepung daun kelor terhadap kadar IL-6 baik pada dosis 0,1 g/BB/hari maupun dosis 0,2 g/BB/hari sama-sama menurunkan kadar IL-6 hingga mencapai nilai normal. Akan tetapi, hasil uji lanjut Post-Hoc Bonferroni menunjukkan jika dibandingkan dosis 1 dan dosis 2 tidak ada perbedaan yang signifikan artinya setiap dosis memberikan efek yang sama.

Penurunan kadar IL-6 setelah intervensi tepung daun kelor dikaitkan dengan senyawa aktif flavonoid dan vitamin C pada kelor. Senyawa ini dapat menghambat sekresi sitokin proinflamasi. Flavonoid dapat menstabilkan Reactive Oxygen Species (ROS) dengan cara bereaksi dengan senyawa reaktif dari radikal, sehingga radikal menjadi inaktif dan inflamasi dapat menurun (Mataheru., 2020) dengan demikian, dapat melindungi struktur sel. Manfaat lain flavonoid yaitu bersama dengan vitamin C mencegah terjadinya oksidasi LDL (Wibawa et al., 2020). Kandungan beta sitosterol pada daun kelor juga berperan dalam metabolisme lemak dengan mekanisme peningkatan ekskresi kolesterol yang dibuang dalam bentuk asam empedu, peningkatan kadar kolesterol HDL, dan penurunan penyerapan kembali asam empedu serta konversinya menjadi kolesterol (Wahyu et al., 2019).

Penelitian ini dapat dijadikan acuan pengembangan pangan fungsional, akan tetapi dosis yang digunakan dalam penelitian ini masih menggunakan batas dosis toksisitas untuk hewan coba. Untuk itu, masih diperlukan studi lebih lanjut pada standarisasi tepung daun kelor untuk pengembangan pangan fungsional berdasarkan dosis yang dianjurkan dalam penelitian ini.

\section{Kesimpulan}

Pemberian tepung daun kelor secara bermakna dapat menurunkan kadar IL-6 dan kolesterol LDL tikus Sprague Dawley yang dikondisikan dislipidemia. Akan tetapi, jika dibandingkan penurunan IL-6 pada dosis 1 dan dosis 2 tidak berbeda signifikan yang berarti setiap dosis memberikan efek yang sama. Intervensi tepung daun kelor terhadap kadar kolesterol LDL baik pada dosis 0,1 g/BB/hari maupun dosis 0,2 g/BB/hari mampu menurunkan kadar kolesterol LDL dimana penurunan lebih besar terjadi pada intervensi dosis 2 yaitu $0,2 \mathrm{~g} / \mathrm{BB} / \mathrm{hari}$.

Hasil penelitian ini dapat dijadikan acuan untuk mengembangkan pangan fungsional berbahan baku tepung daun kelor untuk memenuhi kebutuhan gizi dan pencegahan penyakit berkaitan dengan kelainan metabolisme lipid. Penelitian selanjutnya dapat melakukan analisis kandungan gizi dalam tepung daun kelor.

\section{Acknowledgement}

Tim peneliti pada kesempatan ini mengucapkan terimakasih kepada semua pihak yang telah terlibat dalam penelitian ini khususnya bagi pengelola Pusat Antar Universitas (PAU) Universitas Gadjah Mada (UGM) Yogyakarta, dan tim laboratorium yang telah membantu jalannya penelitian ini dari awal hingga akhir.

\section{References}

Aborhyem, S., Ismail, H., Agamy, N., \& Tayel, D. (2016). Effect of moringa oleifera on lipid profile in rats. Journal of High Institute of Public Health, 46(1), 8-14. https://doi.org/10.21608/jhiph.2016.202 01

Andini, A. N., \& Ardiaria, M. (2016). Pengaruh pemberian kombinasi minyak rami dengan minyak wijen terhadap kadar trigliserida pada tikus Sprague Dawley dislipidemia. Journal of Nutrition College, 5(4), 555-564. https://doi.org/10.14710/jnc.v5i4.16472

Ariyanti, R., \& Besral, B. (2019). Dyslipidemia associated with hypertension increases the risks for coronary heart disease: A casecontrol study in Harapan Kita hospital, National Cardiovascular Center, Jakarta. Journal of Lipids, 2019, 1-6. 
https://doi.org/10.1155/2019/2517013

Arsana, P. M., Rosandi, R., Manaf, A., Budhiarta, A., \& Hikmat Permana. (2019). Pedoman pengelolaan dislipidemi di Indonesia 2019. In Pb. Perkeni (p. 9). https://doi.org/10.1002/bit.22430

Balitbangkes RI. (2018). Hasil utama Riset Kesehatan Dasar (Riskesdas). In Kementerian Kesehatan Republik Indonesia. Chhikara, N., Kaur, A., Mann, S., Garg, M. K., Sofi, S. A., \& Panghal, A. (2020). Bioactive compounds, associated health benefits and safety considerations of Moringa oleifera L.: an updated review. Nutrition \& Food Science, $\quad 51(2)$, 255-277. https://doi.org/10.1108/NFS-03-20200087

Darrashcytha, P. P., Shiva, M. R., \& Priyambodo, S. (2017). Pengaruh pemberian ekstrak daun kelor (Moringa oleifera) terhadap kadar trigliserida dan high density lipoprotein pada tikus putih (Rattus norvegicus) dislipidemia. Jurnal Kedokteran Universitas Mataram, 6(3.1), 50-58.

Erwinanto. (2013). Pedoman tatalaksana dislipidemia (1st ed.). (Perhimpunan Kardiovaskular Dokter ), Spesialis Indonesia.

Erwinanto. (2017). Panduan tata laksana dislipidemia. Perhimpunan Dokter Spesialis Kardiovaskular Indonesia.

Ferreira, R., Bernardino, Liliana, \& Passani, Maria B. (2020). Quantikine ELISA Rat IL-6 Immunoassay. USA R\&D Systems, Inc.

Helmy, S. A., Morsy, N. F. S., Elaby, S. M., \& Ghaly, M. A. A. (2017). Hypolipidemic effect of moringa oleifera lam leaf powder and its extract in diet-induced hypercholesterolemic rats. Journal of Medicinal Food, 20(8), 755-762. https://doi.org/10.1089/jmf.2016.0155

Irwan, Z., Salim, A., \& Adam, A. (2020). Pemberian cookies tepung daun dan biji kelor terhadap berat badan dan status gizi anak balita di wilayah kerja Puskesmas Tampa Padang. AcTion: Aceh Nutrition Journal, 5(1), $\quad$ 45-54. http://dx.doi.org/10.30867/action.v5i1.1 98

Isnan, W., \& Muin, N. (2017). Ragam manfaat tanaman kelor (Moringa oleifera Lamk) bagi masyarakat. Buletin Eboni, 14(1), 6375. https://doi.org/10.20886/buleboni.5096

Linton, M. F., Yancey, P. G., Davies, S. S., Jerome, W. G., Linton, E. F., Song, W. L., Doran, A. C., \& Vickers, K. C. (2019). The role of lipids and lipoproteins in atherosclerosis (Endotext [). South Dartmouth (MA): MDText.com, Inc. https://www.ncbi.nlm.nih.gov/sites/book s/NBK343489/

Mataheru, J. S., \& Unitly, A. J. A. (2020). Kajian pemberian ekstrak etanol rumput kebar (Biopythum Petersianum Klotzcsh) terhadap diferensiasi leukosit tikus rattus novergicus terpapar asap rokok. Kalwedo Sains, 1(2), 74-83.

Nandarningtiyas Laras Pratiwi, Hardoko, E. W. (2016). The effect of crude extract alginate Sargassum crassifolium powder for cholesterol total level on rats (Rattus norvegicus). Journal of Innovation and Applied Technology, 2(2), 309-317.

Ngurah, G., Candra, H., Adnyana, I. M., \& Wijaya, P. (2021). Molecular docking kaempferol sebagai antiinflamasi pada aterosklerosis secara in silico molecular docking kaempferol as anti-inflammatory in atherosclerosis in silico. Jurnal Ilmiah Medicamento, 7(1), 13-18. https://doi.org/10.36733/medicamento.v 7i1.1497

Nile, S. H., Keum, Y. S., Nile, A. S., Jalde, S. S., \& Patel, R. V. (2018). Antioxidant, antiinflammatory, and enzyme inhibitory activity of natural plant flavonoids and their synthesized derivatives. Journal of Biochemical and Molecular Toxicology, 32(1), e22002. https://doi.org/10.1002/jbt.22002

Nurhidajah, Astuti, R., \& Nurrahman. (2019). Black rice potential in HDL and LDL profile in sprague dawley rat with high cholesterol diet. IOP Conference Series: Earth and Environmental Science, 292(1), 012019. https://doi.org/10.1088/17551315/292/1/012019

Pirahanchi, Y., Marsidi, J. L., \& Brown, K. N. (2020). Physiology, Endothelial Derived Relaxation Factor (EDRF). StatPearls Publishing. https://europepmc.org/article/nbk/nbk5 37010

Rani, K. C., Ekajayani, N. I., Darmasetiawan, N. kresna, \& Dewi, A. D. rosita. (2019). Kandungan nutrisi tanaman kelor. In 
Journal of Physics A: Mathematical and Theoretical (Vol. 44, Issue 8).

Rejeki, S., Patni, N. M. D., \& Kuswardhani, R. A. T. (2019). Korelasi albumin serum dan interleukin-6 (IL-6) serum pada pasien geriatri di RSUP Sanglah Denpasar Bali Indonesia. Medicina, 50(2), 396-399. https://doi.org/10.15562/medicina.v50i2 .301

Santosa, W. N., \& Baharuddin, B. (2020). Penyakit jantung koroner dan antioksidan. KELUWIH: Jurnal Kesehatan Dan Kedokteran, 1(2), 98-103. https://doi.org/10.24123/kesdok.V1i2.25 66

Stein, R., Ferrari, F., \& Scolari, F. (2019). Genetics, dyslipidemia, and cardiovascular disease: New insights. Current Cardiology Reports, 21(8), $1-12$. https://doi.org/10.1007/s11886-0191161-5

Sudargo, T., Astuti, I., Sholikhah, E. N., Amelia, R., Maknunah, L., Risnhukathulistiwi, M., \& Pranoto, Y. A. (2017). The effect of kersen juice on lipid profile of Spargue Dawley rats: A randomized controlled trial. Asian Journal of Clinical Nutrition, 9(3), 97-103. https://doi.org/10.3923/AJCN.2017.97.103

Syahrial, S., \& Handayani, M. (2020). Pengaruh waktu milling dengan ukuran nano serbuk daun kelor (Moringa oleifera) dan hubunganya dengan bioavailabilitas secara in-vitro dan in-vivo. AcTion: Aceh Nutrition Journal, 5(2), 121-129. https://doi.org/10.30867/action.v5i2.213 Wahyu, S., Arsal, A. S. F., \& Maharani, I. C. (2019).
Efektivitas ekstrak daun kelor (Moringa oleifera) terhadap penurunan kadar kolesterol total pada tikus putih (Rattus novergicus). Green Medical Journal, 1(1), 97-110.

https://doi.org/10.33096/gmj.v1i1.24

WHO. (2000). General Guidelines for Methodologies on Research and Evaluation of Traditional Medicine World Health Organization.

Wibawa, J. C., Wati, L. H., \& Arifin, M. Z. (2020). Mekanisme vitamin C menurunkan stres oksidatif setelah aktivitas fisik. JOSSAE: Journal of Sport Science and Education, 5(1), 57. https://doi.org/10.26740/jossae.v5n1.p57-63

Wulan, D. K., Noviar, H. dan Y. Z. (2017). Pemanfaatan daun katuk (Sauropus Adrogynus) dalam pembuatan teh herbal dengan variasi suhu pengeringan. JOM FAPERTA, P., 4(2), 101-109.

Yoeantafara, A., \& Martini, S. (2017). Pengaruh pola makan terhadap kadar kolesterol. Jurnal MKMI, 13(4), 304-309.

Yunarto, N., Aini, N., Oktoberia, I. S., Sulistyowati, I., \& Kurniatri, A. A. (2019). Aktivitas antioksidan serta penghambatan HMG CoA dan lipase dari kombinasi ekstrak daun binahong-rimpang temu lawak. Jurnal Kefarmasian Indonesia, 9(2), 89-96. https://doi.org/10.22435/jki.v9i2.1930

Zheng, J., Zhou, Y., Li, S., Zhang, P., Zhou, T., Xu, D. P., \& Li, H. Bin. (2017). Effects and mechanisms of fruit and vegetable juices on cardiovascular diseases. International Journal of Molecular Sciences, 18(3), 555. https://doi.org/10.3390/ijms18030555 